\title{
Concanavalin A Prevents Acetylcholine Receptor Redistribution in Xenopus Nerve-Muscle Cultures
}

\author{
Yoshiaki Kidokoro, Barry Brass, ${ }^{1}$ and Hiroshi Kuromi ${ }^{2}$ \\ The Salk Institute, San Diego, California 92138
}

During neuromuscular junction formation ACh receptors accumulate at the nerve-contact region. It has been shown that this is at least partly due to lateral migration of existing receptors in the membrane (Anderson et al., 1977). Randomly diffusing ACh receptor molecules in the membrane may be trapped at the nerve-contact region to form a high receptor density area. If this were the major mechanism, cross-linking $\mathrm{ACh}$ receptors by tetravalent concanavalin $A$ (Con $A$ ) should immobilize receptors and prevent nerve-induced receptor accumulation.

We examined the effect of Con $A$ on nerve-induced receptor accumulation and on the mobility of $\mathrm{ACh}$ receptors in cultured Xenopus muscle cells. ACh receptors were stained with tetramethyl rhodamine conjugated $\alpha$-bungarotoxin. The cells were then treated briefly with $C$ on $A$, and neural tube cells were added to these cultures. The mobility of $\mathrm{ACh}$ receptors was measured by the fluorescence photobleaching recovery method. The Con A treatment prevented rapid diffusion of $\mathrm{ACh}$ receptors as well as nerve-induced receptor accumulation. Functional synapse formation was not inhibited by this treatment. In contrast, divalent succinyl Con A did not affect the mobility of $\mathrm{ACh}$ receptors nor prevent nerve-induced $\mathrm{ACh}$ receptor accumulation. When the Con A concentration was varied, the blocking effect on the nerve-induced receptor accumulation changed in parallel with the mobile fraction of receptors. Newly inserted $A C h$ receptors after the Con A treatment were found to be mobile and to accumulate at the nerve-contact region. In these cultures, new receptors accumulated around old, immobilized receptors in some areas along the nerve contact. This observation suggests that new receptors were inserted elsewhere and migrated to the nerve-contact region surrounding immobilized old ones.

In addition to the accumulation of receptors, the nerve disperses preexisting receptor clusters prior to induction of highdensity regions along the contact area, and, at this early stage, denervation disperses nerve-induced receptor clusters in Xenopus cultures (Kuromi and Kidokoro, 1984a, b). When cultures were treated with Con A, neither of these events occurred, suggesting that these are also diffusion-mediated.

In embryonic muscle cells, prior to innervation, $\mathrm{ACh}$ receptors are diffusely distributed over an entire surface and the nerve induces accumulation of receptors at the contact region during

\footnotetext{
Received July 24, 1985; revised Nov. 19, 1985; accepted Nov. 21, 1985.

We thank Dr. David Schubert at the Salk Institute for encouragement and advice during the experiments. This work was supported by NIH Grant NS11918 and a grant from the Muscular Dystrophy Association of America to Y.K.

Correspondence should be addressed to Yoshi Kidokoro, Jerry Lewis Neuromuscular Research Center, UCLA School of Medicine, Los Angeles, CA 90024.

I Present address: Department of Physiology and Biophysics, University of Miami School of Medicine, 1600 NW 10th Avenue, Miami, FL 33101.

${ }^{2}$ Present address: Department of Neuropharmacology, Brain Research Institute, Chiba University School of Medicine, 1-8-1 Inohana, Chiba 280, Japan.

Copyright (c) 1986 Society for Neuroscience $0270-6474 / 86 / 071941-11 \$ 02.00 / 0$
}

neuromuscular junction formation (Bevan and Steinbach, 1977; Braithwaite and Harris, 1979; Ziskind-Conhaim and Bennett, 1982). In Xenopus cultures, development of the high receptor density region at the subneural muscle membrane was demonstrated to be at least partly due to redistribution of $\mathrm{ACh}$ receptors within the sarcolemma (Anderson and Cohen, 1977; Anderson et al., 1977). To explain this remarkable developmental phenomenon, a simple model, a passive-diffusion trap mechanism, was proposed by Edwards and Frisch (1976). In this model, freely diffusing ACh receptors in the membrane are trapped at the junctional region and eventually form high receptor density areas along the course of nerve contact.

The following findings in the Xenopus nerve-muscle cultures support this model:

1. During ACh receptor cluster formation, initially small clusters emerge from the background at the nerve-muscle contact. These clusters increase in size and in number and fuse to form larger clusters (Kuromi and Kidokoro, 1983; Kuromi et al., 1985). These observations suggest that the molecular mechanism underlying nerve-induced receptor accumulation is different from that in "cap" formation in B lymphocytes. During "capping" the surface immunoglobulin molecules are crosslinked by antibodies to form "micropatches," which subsequently migrate as a whole to one pole of the cell to form a "cap" (Schreiner and Unanue, 1976).

2. Diffusely distributed $\mathrm{ACh}$ receptors move latcrally at a speed fast enough to account for the fastest rate of $\mathrm{ACh}$ receptor cluster formation following innervation and the rate of receptor cluster dispersal after denervation (Kuromi and Kidokoro, 1983, 1984a, b; Kuromi et al., 1985).

3. The great majority of ACh receptors within the nerveinduced clusters are poorly mobile (Kidokoro and Brass, unpublished observations), as reported for receptor clusters in rat myotubes cultured without nerve (Axelrod et al., 1976a, b).

4. In addition to redistribution of existing receptors, preferential insertion of newly formed receptors to the nerve-contact area might significantly contribute to this developmental phenomenon (Bursztajn et al., 1983). In this model we would expect a higher proportion of new receptors at the junctional region. When we stained new and old receptors separately and quantitatively determined their distribution at the newly formed junction, we found that new receptors did not preferentially accumulate at the junctional sites (Kidokoro and Brass, 1985). This contrasts with the situation in chick nerve-muscle cultures, in which preferential insertion was suggested as the major mechanism for receptor accumulation (Role et al., 1985).

Although these observations are compatible with the diffusion trap model, they do not exclude other mechanisms. For example, micropatches might be too small to be observed under the fluorescence microscope, but the basic mechanism might be the same as that for "capping" in lymphocytes. Or receptors could be internalized at one location, transported within the cytoplasm to nerve-contact sites, and then inserted into the surface membrane. To further support the diffusion trap model, 
we wanted to gain evidence that nerve-induced receptor accumulation is closely correlated to the diffusible state of receptors in the membrane.

Concanavalin $\mathrm{A}$ (Con $\mathrm{A}$ ) is a tetravalent lectin that binds to ACh receptors (Brockes and Hall, 1975; Meunier et al., 1974; Nicholson, 1974). In cultured Xenopus muscle cells, pretreatment with Con A prevented the electrophoretic accumulation of ACh receptors (Orida and Poo, 1978). These results suggest that Con A cross-links and immobilizes ACh receptors in the muscle membrane. If nerve-induced $\mathrm{ACh}$ receptor accumulation were primarily the result of lateral migration of receptors, Con A should prevent this process by cross-linking with consequent immobilization of receptors.

Pulse treatment with Con A prevented accumulation of $\mathrm{ACh}$ receptors at the nerve-contact region and dispersal of receptors after denervation. Newly inserted receptors, however, accumulated at the nerve contact region even after old receptors were immobilized by Con A. The percentage of muscle cells with nerve-induced receptor accumulation decreased as receptors were gradually immoblilized with various concentrations of Con A. We will discuss other effects of Con A and alternative interpretation of our results.

Preliminary results of this study have been published elsewhere (Kuromi and Kidokoro, 1983).

\section{Materials and Methods}

\section{Cultures}

Muscle and nerve cells were obtained from embryos of the African clawtoad, Xenopus laevis, and were grown in culture as previously described (Anderson et al., 1977; Kidokoro et al., 1980). After plating, muscle cultures were kept at room temperature for 3-4 d.

\section{Staining of $A C h$ receptors}

For staining of $\mathrm{ACh}$ receptors, culture medium was removed and saved for later use. New culture medium containing $2 \mu \mathrm{M}$ tetramethyl rhodamine-conjugated $\alpha$-bungarotoxin (TMR- $\alpha \mathrm{BT}$ ) was added to the muscle culture and incubated for $60 \mathrm{~min}$. The stained culture was then incubated for $15 \mathrm{~min}$ in culture medium containing various concentrations of Con A (Sigma) or $100 \mu \mathrm{g} / \mathrm{ml}$ succinyl Con A (Suc-Con A; Vector) or in culture medium without added drugs. These treated cultures were washed at least 3 limes with fresh culture medium and were finally transferred into the previously saved medium. Neural tube cells were obtained from a new batch of embryos and added to these treated or control cultures (4-7 neural tubes per dish).

Fluorescence staining (ACh receptor cluster distribution) in the nervecontacted muscle cells was observed under a fluorescence microscope (Zeiss IM35) on the first and second day after addition of neural tube cells. Some cultures were stained again with TMR- $\alpha$ BT after the first observation and reexamined. Receptor staining patterns were classified as follows: When large clusters of ACh receptors (about $1-5 \mu \mathrm{m}$ long) or double-band structures were associated with the nerve-contact area (see micrographs in Kidokoro et al., 1980), the muscle cell was classified as ACh receptor accumulation (+). When a few small speckles of ACh receptor clusters were associated with the nerve-contact path, or when the nerve contacted the muscle along the edge, it was classified as ACh receptor accumulation $( \pm)$ for the following reasons: Small speckles were often scattered over the muscle surface, and it was quite likely that a few of them were associated with the nerve-contact path even though the nerve was not inducing ACh receptor clusters. Furthermore, Xenopus muscle cells in culture often have ACh receptor clusters along the edge, and it was difficult to distinguish nerve-induced clusters from clusters normally found at the edge. When there were no $\mathrm{ACh}$ receptor clusters along the nerve, the cell was classified as ACh receptor accumulation (-). Receptor clusters were often seen elsewhere in these cases.

For denervation experiments, neural tube cells were added to muscle cultures. After 1 or $2 \mathrm{~d}$ of co-incubation, $\mathrm{ACh}$ receptors were stained with TMR- $\alpha \mathrm{BT}$ as described above; subsequently, these cultures were treated with $100 \mu \mathrm{g} / \mathrm{ml}$ Con $A$ for $15 \mathrm{~min}$. Cultures without the drug treatment were used as controls. After washing, nerve-contacted musclc cells were examined under the fluorescence microscope. Muscle cells with characteristic receptor clusters along the nerve were identified and photographed (15 sec exposure). The coordinates of the microscope stage and rough sketches of the area surrounding the cell were recorded for later relocation of the identified cell. Denervation was performed mechanically using a glass micropipette. The nerves were easily pulled away without distorting muscle cells even after induction of extensive receptor accumulation. About $20 \%$ of identified cells were left without denervation and served as controls. Approximately $4 \mathrm{hr}$ after denervation, previously identified muscle cells were relocated and photographed.

Photomicrographs were taken on the Zeiss inverted microscope (Zeiss $1 \mathrm{M} 35$ ) using Kodak Tri-X film and processed for $14 \mathrm{~min}$ at $20-22^{\circ} \mathrm{C}$ with Kodak Microdol (diluted 1:3). The film was fixed with Rapid-fix (Kodak) for $3 \mathrm{~min}$ and then washcd for $30 \mathrm{~min}$.

\section{Mobility measurement of ACh receptors}

The mobility of $\mathrm{ACh}$ receptors in the muscle membrane was assessed by estimating the diffusion coefficient of TMR- $\alpha \mathrm{BT}$-labeled ACh receptors by the fluorescence photobleaching recovery method previously reported (Axelrod et al., 1976a, b). For photobleaching, a small area of the muscle membrane $(w=1.3 \mu \mathrm{m}$, where $w$ is a half-width of the beam at the $e^{-2}$ height in intensity) was exposed to an intense light for 10 or 20 msec. Recovery of fluorescence was monitored continuously with the attenuated laser beam. The output of the photomultiplier was measured for $204.8 \mathrm{sec}$ with a $200 \mathrm{msec}$ dwell time, or for $102.4 \mathrm{sec}$ with a $100 \mathrm{msec}$ dwell time. These experiments were carried out on the muscle cells at various intervals after treatment with Con A (5-500 $\mu \mathrm{g} /$ $\mathrm{ml})$ or Suc-Con A $(100 \mu \mathrm{g} / \mathrm{ml})$ or without treatment. The mobility of $A C h$ receptors inserted after the treatment with unlabeled $\alpha \mathrm{BT}$ and Con $A$ was measured 1 or $2 \mathrm{~d}$ later after staining with TMR- $\alpha$ BT. The diffusion coefficient was estimated by fitting a curve to the fluorescence recovery with 3 adjustable parameters, namely, characteristic diffusion time, bleaching parameter, and percentage of recovery. These parameters can be estimated reliably by the curve-fitting procedure only when they are within a certain range. When the parameters are outside of the appropriate range, the observation period has to be changed by choosing a different dwell time. When the percentage of recovery was small $(<20 \%)$ during the observation period, as in Con A-treated cultures, the estimates scattered in a wide range and became unreliable. Therefore, in order to compare the effect of various concentrations of Con $A$ on receptor mobility, we used an apparent recovery index defined differently from above-mentioned percentage of recovery. Thus, with the standard 200 msec dwell time, all points $(50-100)$ prior to a bleach pulse were averaged and used as prebleach level of fluorescence intensity $\left(l_{\text {pre }}\right)$. The fluorescence intensity immediately after the bleach pulse was obtained by averaging 10 points $\left(l_{0}\right)$, and at the end of observation (200 sec, $\left.l_{200}\right)$ it was obtained by averaging 100 points. The apparent recovery index $(A R)$ is defined as

$$
A R=\left(l_{200}-l_{0}\right) /\left(l_{\text {pre }}-l_{0}\right)
$$

This value was $88 \pm 17 \%$ (mean $\pm \mathrm{SD}, n=46$ ) of that of the recovery parameter obtained by curve fitting in control cultures. We considered the portion of fluorescence that did not recover during the observation period as a "poorly mobile" fraction of surface receptors, because even those receptors may move at a much slower rate (Stya and Axelrod, 1983).

\section{Measurement of synaptic potentials}

Spontaneous synaptic potentials (miniature endplate potentials, mepps) were recorded on an FM tape recorder (Racal) using the giga-seal technique described previously (Kidokoro, 1984). In off-line computer analyses (Digital PDP 11/23), mepps with an amplitude greater than 0.5 $\mathrm{mV}$ were digitized with a sampling interval of $0.5 \mathrm{msec}$. The mean amplitude was calculated from 50 to 100 individual mepps. As described previously (Kidokoro, 1984; Kidokoro et al., 1980), there are many mepps whose amplitude is smaller than $0.5 \mathrm{mV}$ in this preparation. Therefore, our estimate of the mean mepp amplitude is undoubtedly biased toward a greater value. However, this problem does not affect the conclusions drawn in this study. All experiments were carried out at room temperature $\left(22-23^{\circ} \mathrm{C}\right)$.

\section{Results}

Binding of Con $A$ and Suc-Con $A$ to $A C h$ receptors Con $A$ has been shown to bind solubilized ACh receptors (Brockes and Hall, 1975; Meunier et al., 1974). Also, Orida and Poo 
(1978) have shown that pretreatment of cultured Xenopus muscle cells with Con A prevents asymmetrical distribution of $\mathrm{ACh}$ sensitivity induced by an electric field. Thus, it is likely that Con A binds to ACh reccptors in culturcd Xenopus muscle cells.

To confirm this point we stained muscle cells with fluoresceinconjugated Con A (FITC-Con A; Cappel). As shown in Figure $1 C$, the muscle cells stained diffusely with irregularly shaped high receptor density regions. When these cells were stained again with TMR- $\alpha \mathrm{BT}$, some of the regions were doubly stained (compare Fig. 1, $B$ and $C$ ). All clusters of $\alpha \mathrm{BT}$ binding sites were stained with FITC-Con A. It is obvious, however, that the distribution of Con $\mathrm{A}$ receptors is much wider than that of $\alpha \mathrm{BT}$ binding sites. This was expected, since Con A binds as well to other unidentified surface molecules.

Suc-Con A was expected to bind to the Con A binding sites (Gunther et al., 1973). Indeed pretreatment with $100 \mu \mathrm{g} / \mathrm{ml}$ SucCon A inhibited staining of muscle cells by FITC-Con A. It is thus most likely that Con $\mathrm{A}$, as well as Suc-Con $\mathrm{A}$, binds to the $\mathrm{ACh}$ receptor in Xenopus muscle cells.

\section{Effect of Con $A$ and Suc-Con A on nerve-induced ACh receptor accumulation}

Muscle cells were first stained with TMR- $\alpha$ BT and incubated for $15 \mathrm{~min}$ with $100 \mu \mathrm{g} / \mathrm{ml}$ Con A or $100 \mu \mathrm{g} / \mathrm{ml} \mathrm{Suc-Con} \mathrm{A.}$ Cultures were washed thoroughly and neurons added. Two days later the distribution of receptor clusters was examined under a fluorescence microscope.

Table 1 shows the results of Con A and Suc-Con A treatment on ACh receptor cluster distribution. The formation of $\mathrm{ACh}$ receptor clusters at the nerve-muscle contact was determined according to the criteria described in Materials and Methods. A total of 80 nerve-contacted muscle cells in 4 Con A-treated cultures and 62 nerve-contacted muscle cells in 3 Suc-Con A treated cultures were examined. In control cultures, about $60 \%$ of nerve-contacted muscle cells at day 2 of co-incubation exhibited typical $\mathrm{ACh}$ receptor cluster distribution; that is, several receptor clusters were aligned along the path of nerve contact and receptor clusters were rarely observed at the extrajunctional region (Fig. 2, $A$ and $D$ ). In contrast, in Con A-treated cultures, no distinct $\mathrm{ACh}$ receptor accumulation was observed along the path of nerve-muscle contacts, and large $\mathrm{ACh}$ receptor clusters remained at the extrajunctional region (Fig. 2, $B$ and $E$ ). In SucCon A-treated cultures, however, there was no difference from control in the distribution of receptor clusters (Fig. 2, $C$ and $F$ ).

Thus, tetravalent Con $A$ inhibited nerve-induced receptor accumulation, as well as dispersal of clusters in the extrajunctional region, but divalent Suc-Con A did not.

Control cultures restained with TMR $-\alpha$ BT exhibited increased fluorescence intensity compared with unstained cultures, but the pattern of cluster distribution was the same. In Con A-treated cultures, ACh receptor clusters became noticeable at the nerve-muscle contacts after restaining on the second day, and the percentage of nerve-contacted muscle cells that had no $\mathrm{ACh}$ receptor clusters along the nerve contact decreased from 87.5 to $40.0 \%$. Although in this experiment we did not find muscle cells with typical nerve-induced receptor accumulation, the $( \pm)$ category, which probably contains some nerve-induced accumulation, increased correspondingly from 12.5 to $60 \%$ (Table 1). Since the fluorescent clusters that became visible after restaining are considered as receptors inserted after the first staining, it is concluded that ACh receptors cross-linked by Con A were inhibited from accumulating at the nerve-muscle contact, but newly inserted ones were not. This result suggests either that newly synthesized receptors were preferentially inserted at the nerve-contact region or that new receptors were inserted elsewhere and accumulated at the junctional site by lateral diffusion. The latter possibility was further tested by measuring the lateral mobility of newly inserted receptors, as will be described below.
Mobility of ACh receptors after Con A or Suc-Con A treatment It has been shown in cultured rat muscle cells with the fluorescence photobleaching recovery method that lateral movement of $\mathrm{ACh}$ receptors was inhibited by Con A treatment (Axelrod et al., 1978). With the same method we measured the mobility of $\mathrm{ACh}$ receptors after treatment with Con A or Suc-Con A. Figure 3 shows typical fluorescence recovery curves after bleaching in control (Fig. 3A) and Con A-treated muscle cells (Fig. $3 B$ ). In control cultures, approximately $65 \%$ of $A C h$ receptors in the diffusely distributed region were mobile, while the majority of those in clusters were poorly mobile. After Con A treatment a majority of $\mathrm{ACh}$ receptors in the diffusely distributed area also became poorly mobile (Fig. $3 B$ ). In contrast to Con A treatment, Suc-Con A did not significantly change the mobility of $\mathrm{ACh}$ receptors. The diffusion coefficient and the percentage of recovery after bleaching of diffusely distributed ACh receptors were $2.3 \pm 0.08 \times 10^{-10} \mathrm{~cm}^{2} / \mathrm{sec}$ (mean $\pm \mathrm{SEM}$ ) at $22^{\circ} \mathrm{C}$ and $64.2 \pm 7.9 \%$, respectively, in Suc-Con A-treated cultures $(n=5)$. These values were similar to those obtained in control cultures: diffusion coefficient, $2.4 \pm 0.07 \times 10^{-10} \mathrm{~cm}^{2} /$ sec; percentage of recovery, $68.2 \pm 5.5 \%, n=5$. This value for the diffusion coefficient in control cultures is about 10 times smaller than that previously published by Poo (1982). We cannot offer an explanation for this discrepancy.

Local binding of Con $A$ to mouse fibroblasts inhibits the mobility of surface molecules over the entire surface (Schlessinger et al., 1977a, b). If this effect prevails in Xenopus muscle cells, newly inserted receptors might not be mobile if old receptors were immobilized by Con A treatment. One or 2 days after Con A treatment, receptors were labeled with TMR- $\alpha \mathrm{BT}$ and photobleaching recovery experiments performed. The percentage of recovery and the diffusion coefficient were $47 \pm 4 \%$ $(n=10)$ and $3.0 \pm 0.2 \times 10^{-10} \mathrm{~cm}^{2} / \mathrm{sec}(n=9)$, respectively. Since receptors cross-linked by Con A are practically immobile, this recovery from photobleaching must have been due to new receptors inserted after the Con A treatment. Thus, we concluded that newly inserted receptors after the Con $\mathrm{A}$ treatment were mobile.

\section{Functional synaptic transmission in Con A-treated muscle cells}

We tested the effect of the Con A treatment on functional synaptic transmission. Muscle cultures were treated with $100 \mu \mathrm{g} /$ $\mathrm{ml}$ Con A for $15 \mathrm{~min}$ and thoroughly washed with culture medium; neuronal cells were then added. Small and infrequent mepps were detected the next day; $2 \mathrm{~d}$ after the Con A treatment, mepps were frequently encountered in nerve-contacted muscle cells. The mean amplitude was $3.7 \pm 1.1 \mathrm{mV}(n=7)$, which was close to that in control cells, $4.9 \pm 1.1 \mathrm{mV}(n=7)$. The resting membrane potential in Con A-treated cells was $-80 \pm$ $2 \mathrm{mV}(n=8)$, which was not different from that in control cclls $(-81 \pm 2 \mathrm{mV}, n=5)$. The large mepp amplitude in some cases after $2 \mathrm{~d}$ of the Con $\mathrm{A}$ treatment suggests that $\mathrm{ACh}$ receptor accumulation occurred at the sites of $\mathrm{ACh}$ release (Kidokoro et al., 1980). This agrees with the result that some nerve contacts showed nerve-associated clusters after restaining (Table 1 ). Thus, the Con A treatment does not appear to affect nerve transmitter secretion.

\section{Effects of various concentrations of Con $A$ on nerve-induced receptor accumulation}

In the experiment described earlier we used a high concentration of Con $A(100 \mu \mathrm{g} / \mathrm{ml})$ to test its effect on nerve-induced receptor accumulation and on the mobility of ACh receptors in the membrane. If Con $A$ affects receptor accumulation by decreasing the receptor mobility, the concentration dependence of these 2 effects should be similar.

Muscle cultures were stained for ACh receptors with TMR- 
A

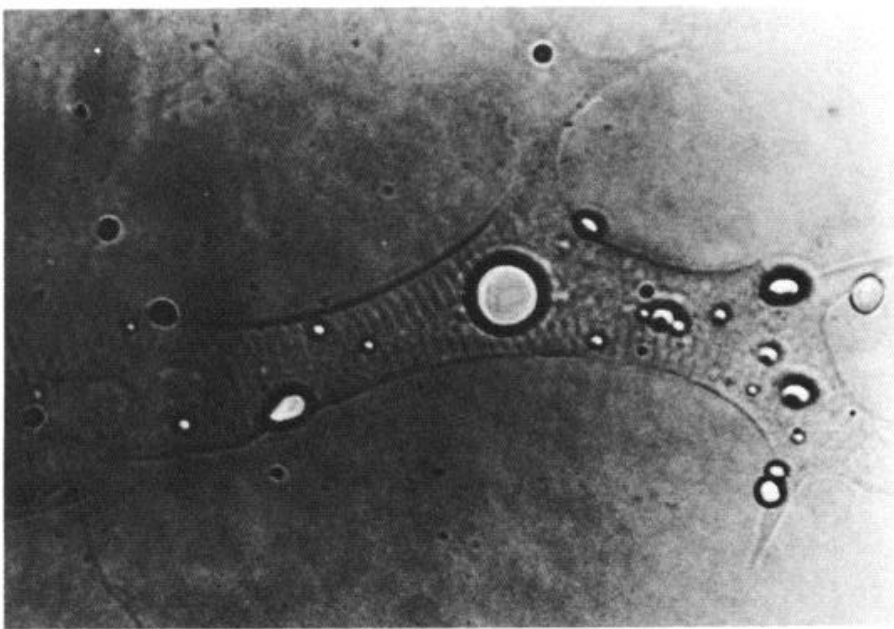

B

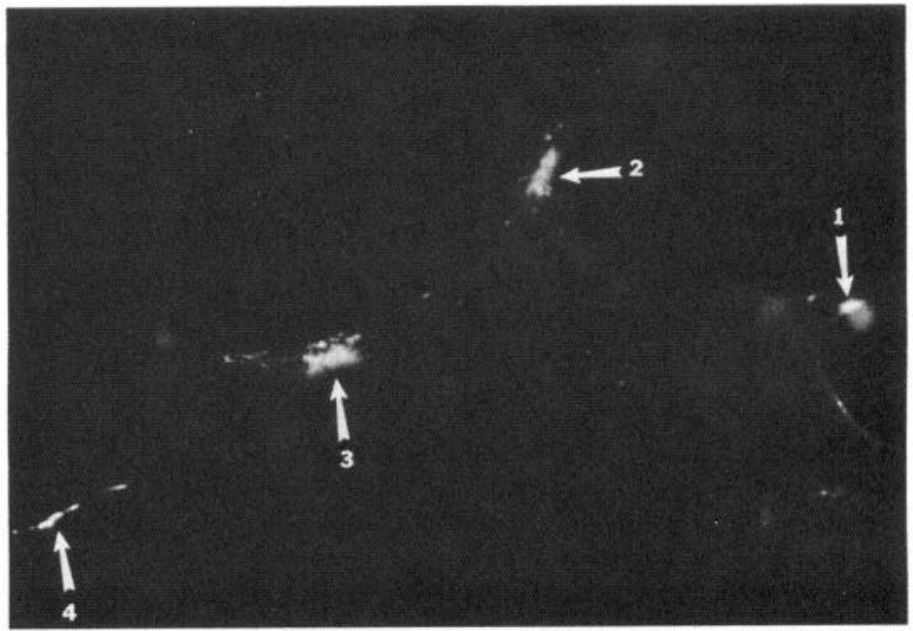

R-aBT

Figure 1. Distribution of $\mathrm{ACh}$ receptors and Con $\mathrm{A}$ receptors on the muscle cell. Four-day-old muscle cell was stained with TMR- $\alpha$ BT $(2 \mu \mathrm{M}$ for $60 \mathrm{~min})$ and then stained with FITCCon $\mathrm{A}(50 \mu \mathrm{g} / \mathrm{ml}$ for $15 \mathrm{~min})$. $A$, Phasecontrast view. $B$, Photograph with rhodamine optics. $C$, Photograph of the same field with fluorescein optics. Arrows in $B$ indicate receptor clusters; arrows in $C$ are corresponding binding sites for Con A. Scale bar, $10 \mu \mathrm{m}$.

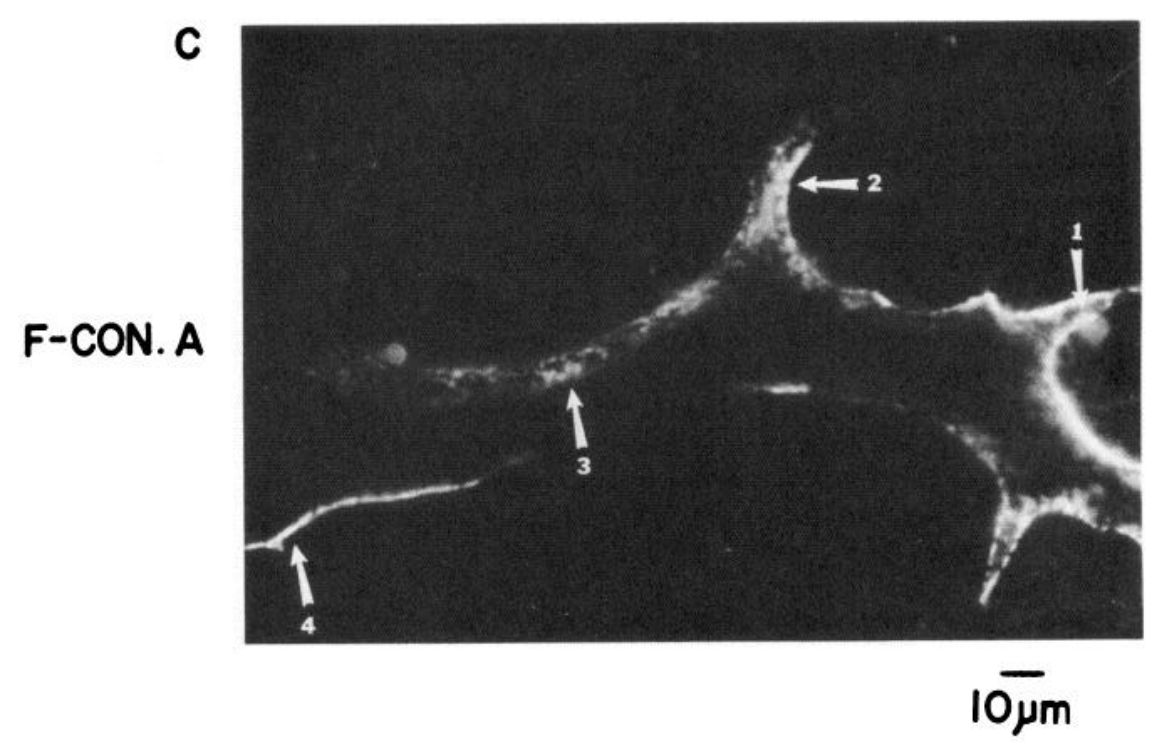

$\alpha \mathrm{BT}$ and subsequently treated for $15 \mathrm{~min}$ with various concentrations of Con A. Cells were then washed 3 times with normal culture medium and freshly dissected nerve cells were added. These cultures were examined under a fluorescence microscope for the receptor cluster distribution after 1 or $2 \mathrm{~d}$ of coculture, and the percentage of nerve-contacted muscle cells exhibiting typical nerve-induced receptor accumulation was determined. The details of this assay are described in Materials and Methods. In control cultures not treated with Con A, $32 \pm 6.9 \%(n=$ 8) of nerve-contacted muscle cells had nerve-induced receptor 


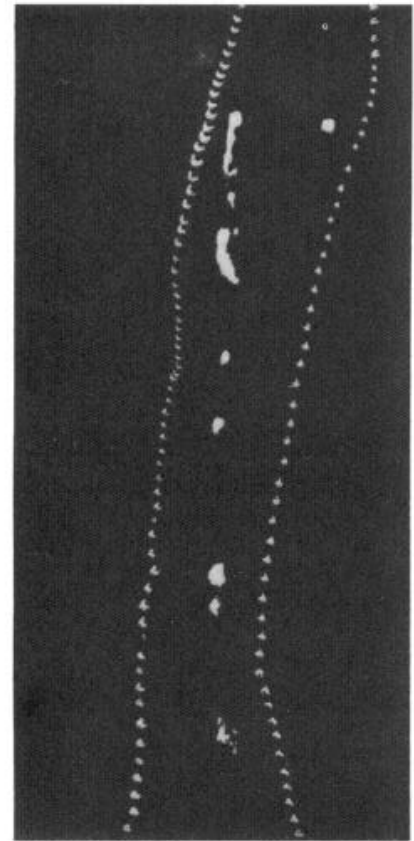

อ

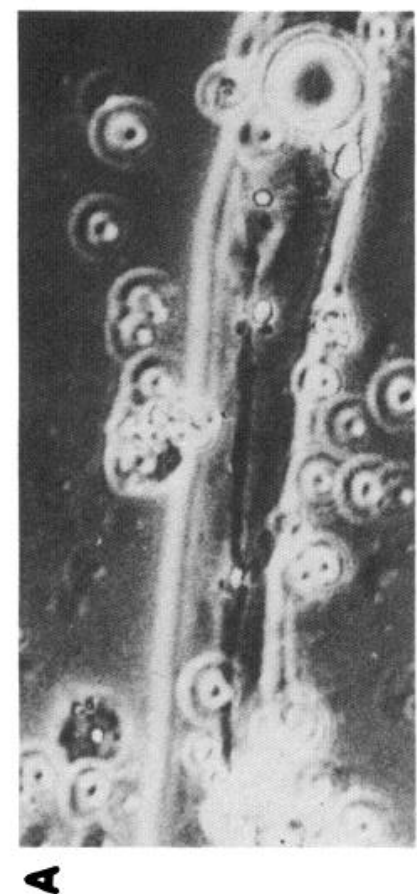

$\frac{1}{0}$

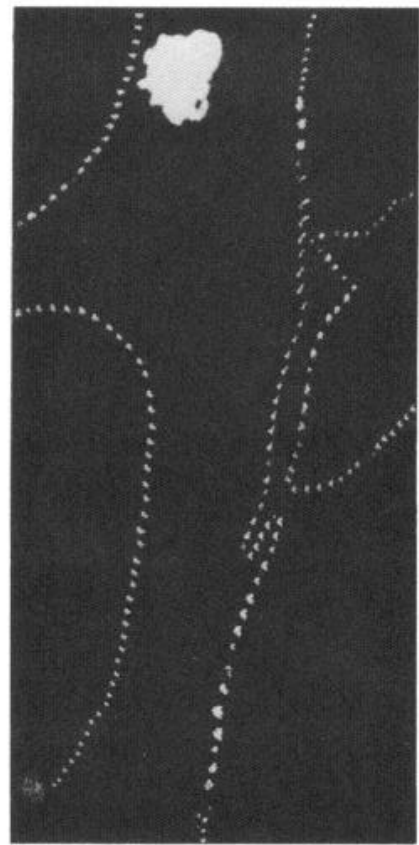

II

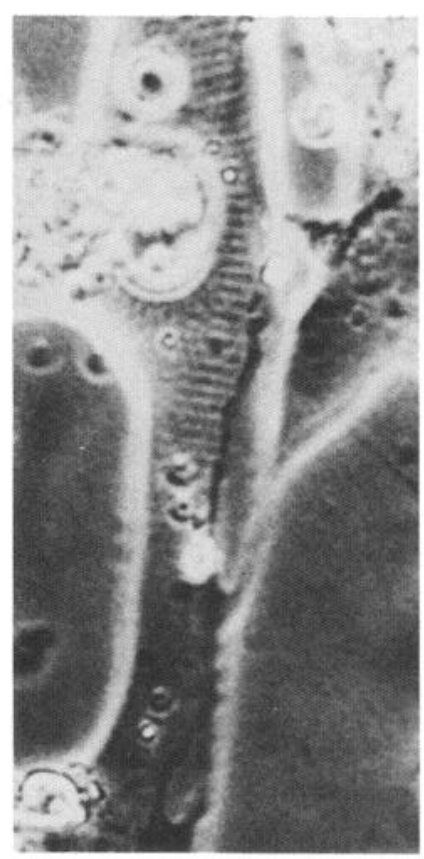

m

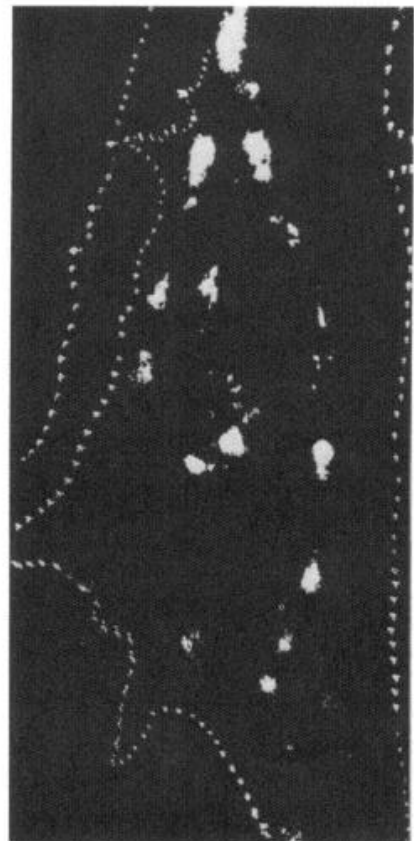

12

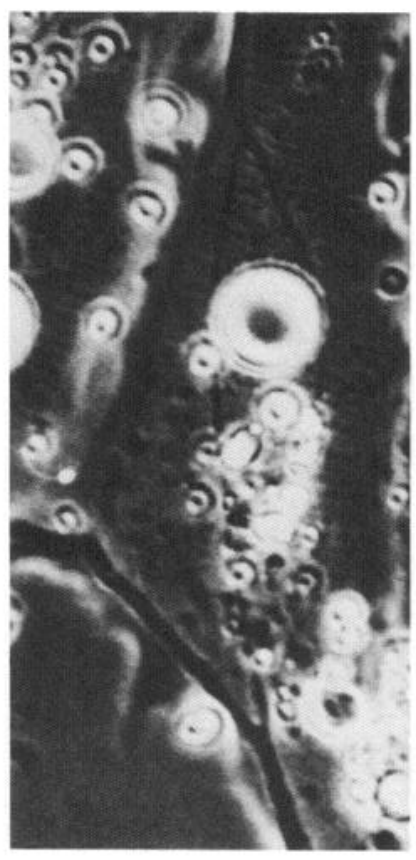

3

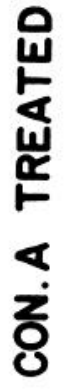

品

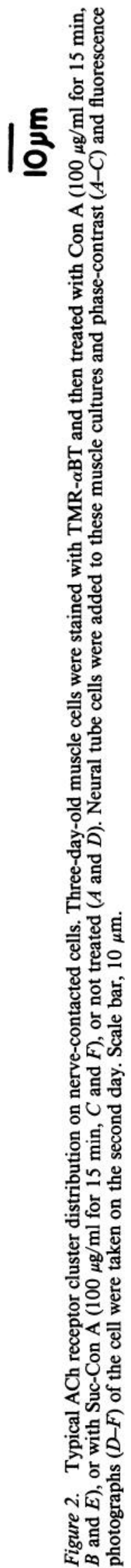


Table 1. ACh receptor cluster formation at the nerve-muscle contact in Con A- and Suc-Con A-treated and control muscle cells

ACh receptor cluster formation $(\% \pm \mathrm{SD})$

\begin{tabular}{|c|c|c|c|c|c|c|c|c|c|}
\hline & \multicolumn{3}{|l|}{ Day 1} & \multicolumn{3}{|l|}{ Day 2} & \multicolumn{3}{|c|}{ Day 2, restained } \\
\hline & - & \pm & + & - & \pm & + & - & \pm & + \\
\hline $\begin{array}{l}\text { Control } \\
\qquad(100 ; 5)\end{array}$ & $43.0 \pm 6.6$ & $24.0 \pm 3.3$ & $33.4 \pm 3.4$ & $27.0 \pm 5.8$ & $14.0 \pm 5.8$ & $59.0 \pm 5.3$ & $21.0 \pm 3.9$ & $22.0 \pm 6.0$ & $57.0 \pm 4.1$ \\
\hline $\begin{array}{l}\text { Con A } \\
(80 ; 4)\end{array}$ & $100^{*}$ & $0^{*}$ & $0^{*}$ & $87.5^{*} \pm 5.2$ & $12.5^{*} \pm 4.3$ & $0^{*}$ & $40.0^{*} \pm 3.6$ & $60.0^{*} \pm 5.3$ & $0^{*}$ \\
\hline $\begin{array}{c}\text { Suc-Con A } \\
(62 ; 3)\end{array}$ & $47.0 \pm 6.5$ & $22.0 \pm 5.0$ & $31.0 \pm 4.7$ & $25.0 \pm 5.0$ & $15.0 \pm 1.7$ & $60.0 \pm 5.8$ & & & \\
\hline
\end{tabular}

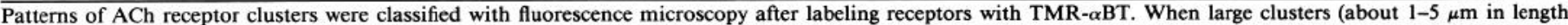

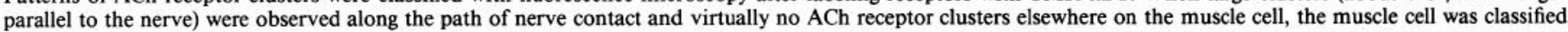

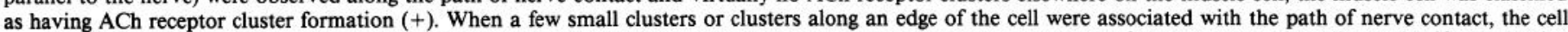

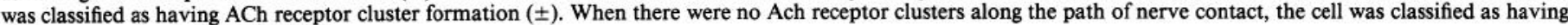
ACh receptor cluster formation (-).

* Significant difference $(p<0.001)$ compared to control value. In parentheses, numbers of cells and numbers of cultures, respectively.

accumulation at $1 \mathrm{~d}$ of coculture. This percentage increased slightly by the second day to $44.4 \pm 7.9(n=14$, Fig. 4$)$. This indicates that nerve-induced receptor accumulation was still progressing after $1 \mathrm{~d}$ of coculture.

With low concentrations of Con A (5 and $20 \mu \mathrm{g} / \mathrm{ml})$, the percentage did not differ from control either at day 1 or 2 . At
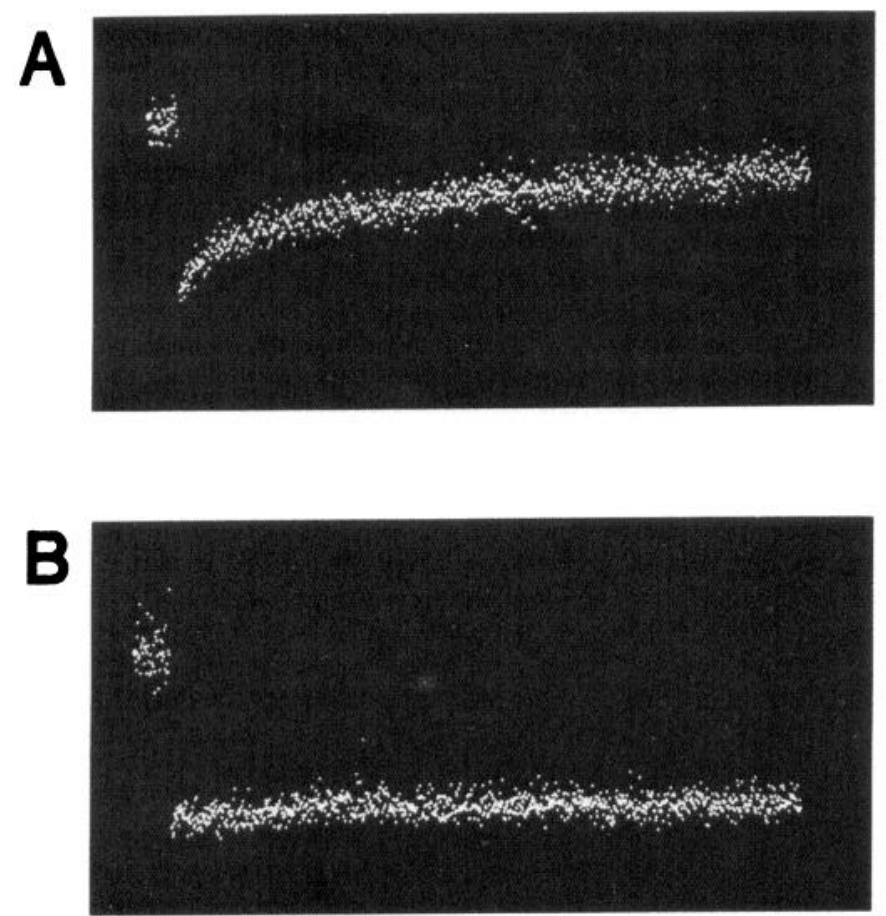

Figure 3. Fluorescence photobleaching recovery curves of TMR- $\alpha \mathrm{BT}$. TMR- $\alpha$ BT-stained muscle cells were incubated in $100 \mu \mathrm{g} / \mathrm{ml}$ of Con A for $15 \mathrm{~min}(B)$ or in culture medium $(A)$, and were washed at least 3 times with culture medium. Measurements were performed on the muscle cells at room temperature $\left(22-23^{\circ} \mathrm{C}\right)$. Note that the bleached TMR$\alpha \mathrm{BT}$ fluorescence in diffuse areas recovered during the observation period of approximately $200 \mathrm{sec}$ after the bleach pulse $(20 \mathrm{msec})$ in control muscles $(A$, the average percentage of recovery is about $70 \%)$, but the recovery was slow in Con A-treated muscles $(B)$. Total length of the bar at the bottom is $100 \mathrm{sec}$.
$50 \mu \mathrm{g} / \mathrm{ml}$, however, the percentage was significantly lower, $7.6 \pm$ $4.1(n=7)$, than control at day 1 but increased almost to control level, $35.8 \pm 13.7(n=11)$, at day 2 . Note that the variation here is larger. It appears that at $50 \mu \mathrm{g} / \mathrm{ml}$ Con A, receptors accumulate more slowly. At $100 \mu \mathrm{g} / \mathrm{ml}$, the percentage was 4 and $0 \%$ of 2 cultures at day 1 and $9.3 \pm 7.4(n=6)$ at day 2 , confirming the earlier result. However, although it was not previously noticed, there occasionally was unambiguous nerve-induced receptor accumulation at day 2 .

Thus, $100 \mu \mathrm{g} / \mathrm{ml}$ Con A was the minimal concentration needed to block nerve-induced receptor accumulation at both day 1 and 2 of coculture. The slower onset of nerve-induced receptor accumulation at $50 \mu \mathrm{g} / \mathrm{ml}$ Con A could be due to one of several mechanisms. Con A might slowly dissociate from its binding sites, or ACh receptors associated with Con A might diffuse in the membrane at a slower rate. These possibilities can be distinguished by measuring the mobility and mobile fraction of ACh receptors with the fluorescence photobleaching recovery technique described below.

\section{Effects of various concentrations of Con A on ACh receptor mobility}

To determine the mechanism of the blocking effect of Con A on nerve-induced receptor accumulation, we measured the mobility and the percentage of diffusible receptors with the fluorescence photobleaching recovery technique (Axelrod et al., 1976a). For the reasons described in Materials and Methods, curve fitting was unreliable with the experimental data, less than $20 \%$ of the bleached fluorescence intensity being recovered during the observation period of approximately $200 \mathrm{sec}$. Therefore, instead of using the percentage recovery derived from curve fitting, we used the apparent recovery index defined in Materials and Methods. This index is a function of both the diffusion coefficient and the percentage of the mobile fraction.

If Con A dissociates slowly from ACh receptors, we would expect the apparent recovery index to increase during culture. The absolute fluorescence intensity declined gradually during culture. This is most likely attributable to turnover of ACh receptors. The apparent recovery index, however, did not change (Table 2). Therefore, Con A seems to remain bound to the site during a culture period of up to $3 \mathrm{~d}$.

The effect of various concentrations of Con A on apparent recovery is shown in Figure 5 . At $10 \mu \mathrm{g} / \mathrm{ml}$ Con $\mathrm{A}$, no effect was found; however, at $20 \mu \mathrm{g} / \mathrm{ml}$, a significant reduction of recovery was observed. At $100 \mu \mathrm{g} / \mathrm{ml}$, only $12 \%$ was recovered, similar to the value at $500 \mu \mathrm{g} / \mathrm{ml}$. There was only a small difference in the effect on the apparent recovery between 50 and 


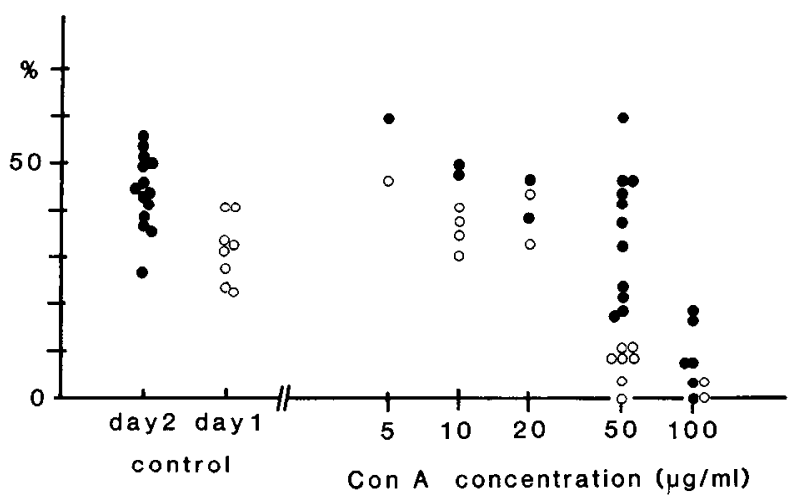

Figure 4. Effects of various concentrations of Con A on nerve-induced receptor accumulation. Percentage of muscle cells that exhibited typical nerve-induced receptor accumulation was plotted on the ordinate against Con A concentrations on the abscissa in a logarithmic scale. Filled circles represent data from 1-d-cocultures; open circles, data from 2-d-old cocultures. Control values (without Con A treatment) are plotted at the left of the graph (bar, 1 SEM).

$100 \mu \mathrm{g} / \mathrm{ml}$ Con $\mathrm{A}$, which contrasts with the difference in the blocking effect on nerve-induced receptor accumulation. At 50 $\mu \mathrm{g} / \mathrm{ml}$ Con $\mathrm{A}$, there was a slow recovery that became evident when the dwell time was increased from the usual $200 \mathrm{msec}$ to $1 \mathrm{sec}$; consequently, recovery was observed approximately at $1000 \mathrm{sec}$. The diffusion coefficient was $5.8 \pm 1.1 \times 10^{-11} \mathrm{~cm}^{2} /$ sec, which is about 4 times slower than that of control cultures. This slower diffusion may have caused the slower onset of nerveinduced receptor accumulation with $50 \mu \mathrm{g} / \mathrm{ml}$ Con A.

\section{Effect of Con $A$ on the dispersal of $A C h$ receptor clusters after denervation}

We have previously shown that nerve-induced receptor clusters along the nerve disperse after denervation, and we suggested that the dispersal of receptor clusters may also be mediated by diffusion of receptors in the membrane (Kuromi and Kidokoro, 1984b). Alternatively, it could be due to accelerated internalization of receptors after denervation. If the former interpretation is correct, cross-linking of receptors by Con A should prevent the dispersal of receptor clusters after denervation.

Nerves were severed mechanically by a glass pipette. In control cultures we confirmed the previous result in 9 cases, namely, that the nerve-induced receptor clusters disperse quickly after

Table 2. Fluorescence recovery from photobleaching after Con $A$
treatment

\begin{tabular}{lc}
$\begin{array}{l}\text { Days after } \\
\text { treatment }\end{array}$ & Apparent recovery \\
\hline $50 \mu \mathrm{g} / \mathrm{ml}$ Con $\mathrm{A}$ & \\
0 & $23 \pm 9 *(n=10)$ \\
1 & $17 \pm 12(n=10)$ \\
2 & $19 \pm 11(n=19)$ \\
$100 \mu \mathrm{g} / \mathrm{ml} \mathrm{Con} \mathrm{A}$ & \\
0 & $8 \pm 8 \quad(n=8)$ \\
1 & $6 \pm 4 \quad(n=7)$ \\
2 & $16 \pm 15(n=16)$
\end{tabular}

Fluorescence due to ACh receptors at the diffusely distributed region was bleached with a $20 \mathrm{msec}$ pulse and recovery measured for approximately $200 \mathrm{sec}$ with a $200 \mathrm{msec}$ dwell time. Apparent recovery index is defined in Materials and Methods. * Mean \pm SD

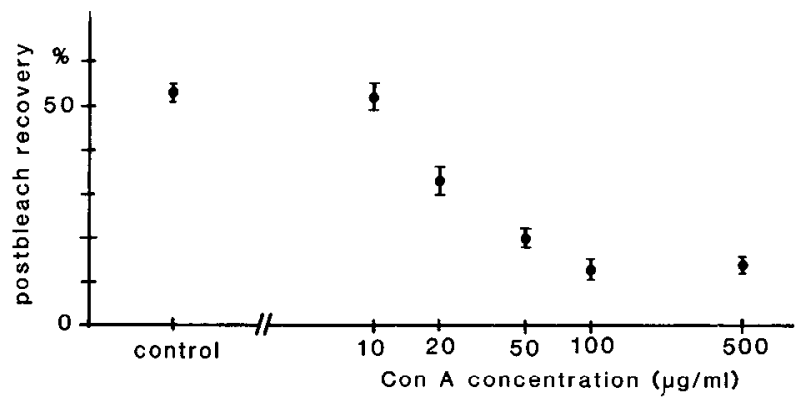

Figure 5. Fluorescence recovery from photobleaching after treatment with various concentrations of Con $A$. Apparent recovery index (defined in Materials and Methods) is plotted on the ordinate against the Con A concentration on the abscissa in a logarithmic scale. Control values (without Con A treatment) are plotted at the left of the graph (bar, 1 SEM).

denervation. As shown in Figure $6, A-C$, only small speckles remained $4 \mathrm{hr}$ after denervation. In contrast, in Con A-treated cultures, receptor clusters remain almost unchanged $4 \mathrm{hr}$ after denervation (Fig. 6, $D-F$ ). In 10 other cells examined, the result was essentially the same. Only in 1 case did clusters seem to be partially dispersed. The cluster distribution in Con A-treated cultures did not differ from that in nerve-contacted muscle cells, in which the nerve was not severed (Fig. 6, $G-I$ ).

This result supports our previous interpretation that dispersal of clusters after denervation is due to diffusion of receptors in the membrane. However, this could be interpreted as that Con A inhibits internalization of receptors after denervation. Con A is known to slow the rate of receptor turnover in cultured chick muscle (Prives et al., 1979).

\section{Distribution of newly inserted receptors after Con A treatment}

We have shown previously that old and new receptors are distributed in the same proportion at the nerve-induced receptor clusters as at the diffusely distributed region (Kidokoro and Brass, 1985). In cultured rat myotubes it has been demonstrated that receptors within the cluster are exchangeable, although slowly, with diffusely distributed ones (Stya and Axelrod, 1983). Therefore, wherever new receptors are inserted, they may mix with old receptors after a period of time. If old receptors are immobilized with $100 \mu \mathrm{g} / \mathrm{ml}$ Con A, the distribution of new receptors inserted after the Con A treatment may accumulate differently at the nerve-contact site.

Nerve-muscle cultures were incubated with Con $A$ after staining with TMR- $\alpha \mathrm{BT}$. After 1 or $2 \mathrm{~d}$, pictures were taken and the cultures were then stained with TMR- $\alpha \mathrm{BT}$ for new receptors. As shown in Figure 7, receptor clusters were associated along the course of nerve contact (Fig. $7 B$, the first exposure; Fig. $7 C$, the second exposure after restaining). Close examination of each cluster revealed that some clusters had an annular shape after restaining, that is, fluorescence intensity at the center of the cluster was weaker than in the surrounding region. An arrow in Figure $7 C$ points to an annular-shaped cluster; the corresponding area in Figure $7 B$ (arrow) has a dense region at the center.

Previously we looked for similar annular structures of receptor clusters in several nerve-muscle cultures not treated with Con A but processed in a fashion similar to that described above. We did not find the characteristic annular structures.

This result can be interpreted in 2 ways. Either new receptors were indeed inserted preferentially at the junctional region, particularly at the periphery of clusters, or new receptors were inserted elsewhere on the surface membrane and then migrated to the nerve-contact region and accumulated at the periphery 


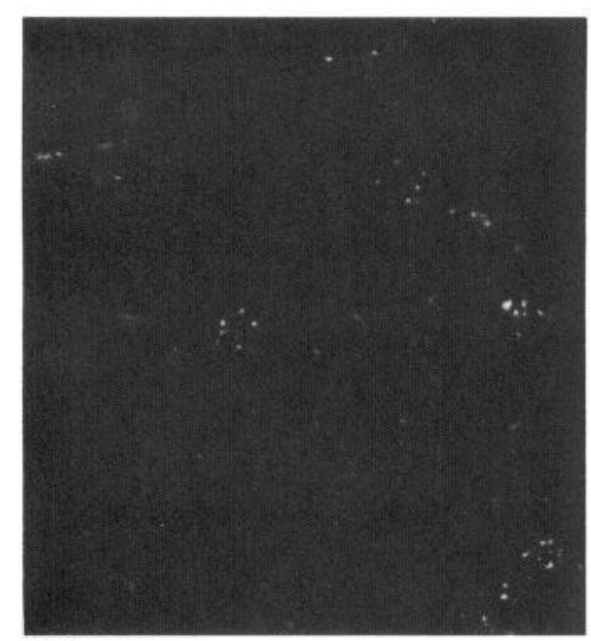

\section{$\cup$}

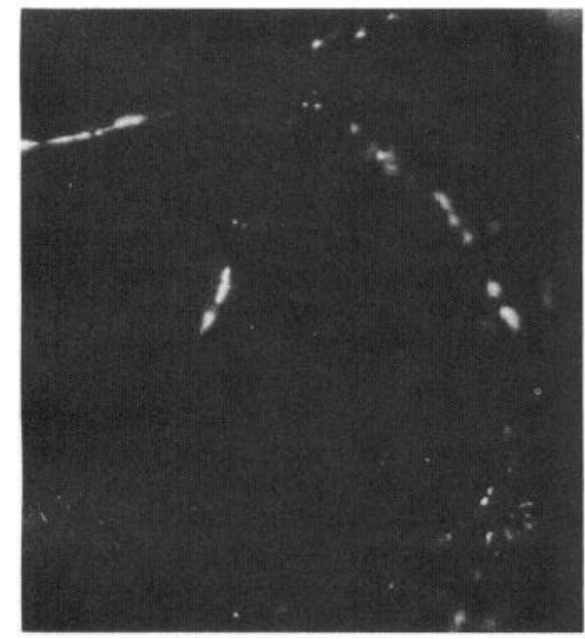

a

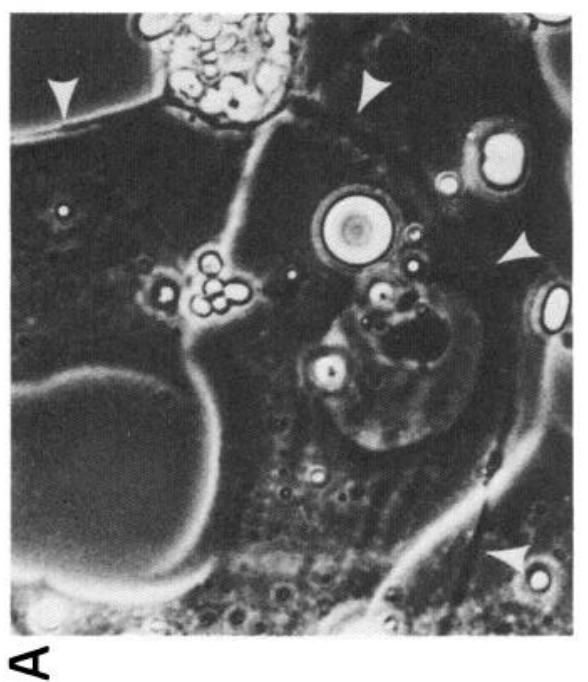

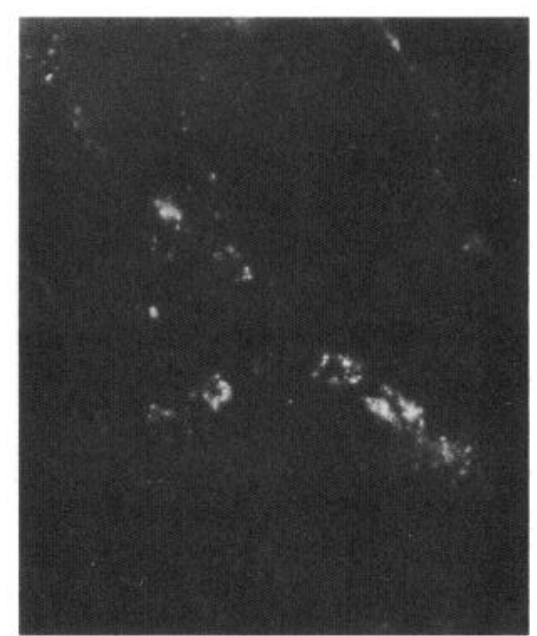

\section{ㄴ.}
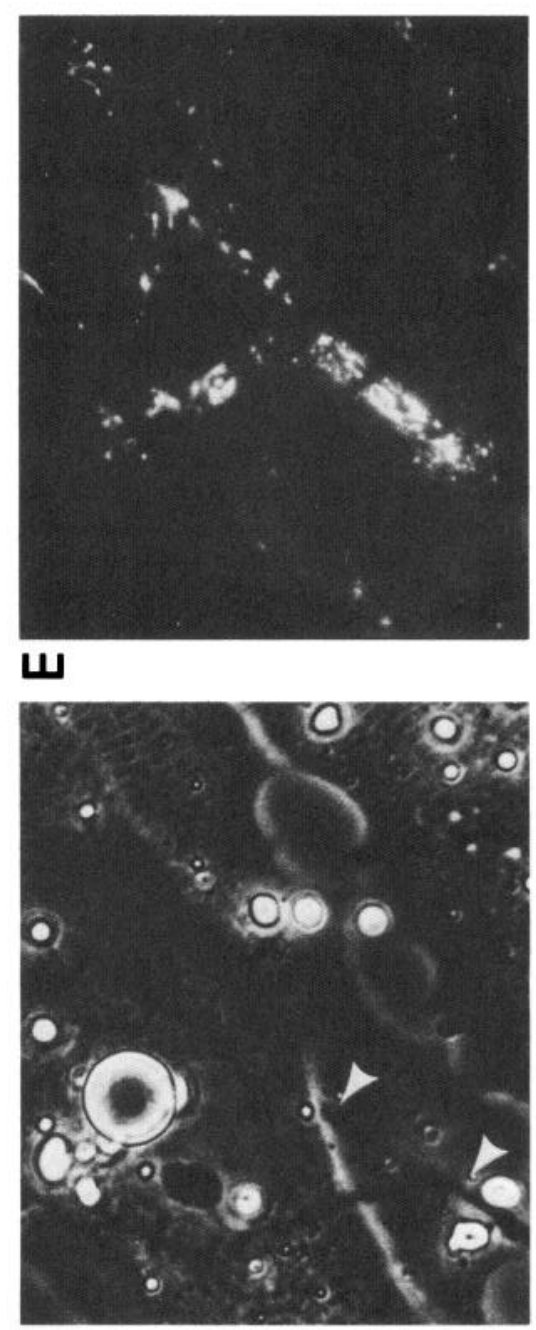

0
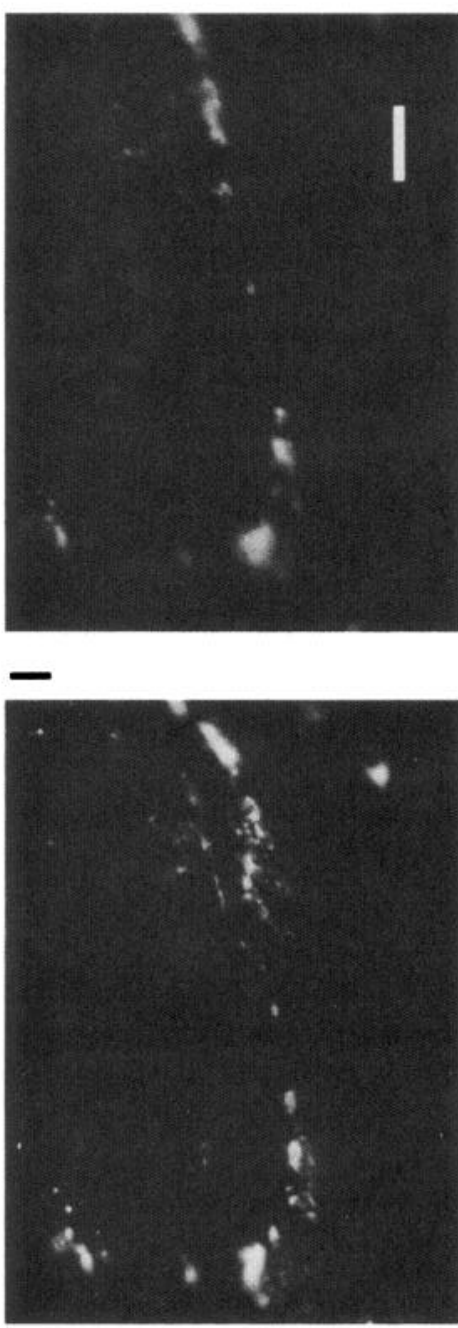

\section{$I$}

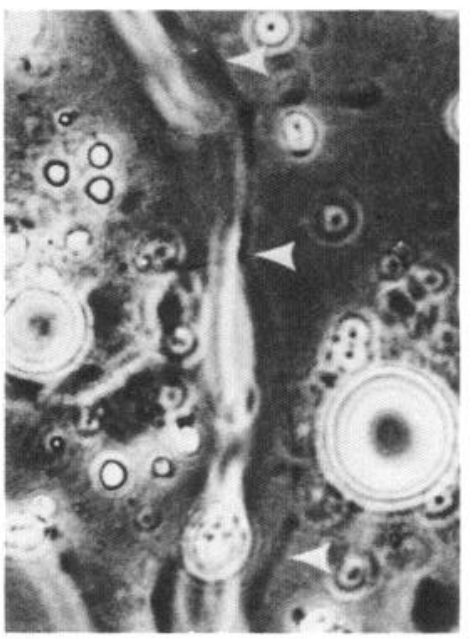

0

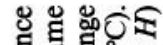

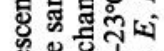

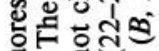

证实

$\infty$ 我表

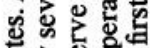

空西品

․․워

․ㅡㄹ

造造

8 学包

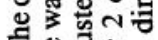

过点

论 包

象家

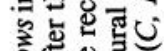

웛

논 过诺

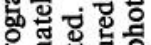

․ㅡㄹ

충르음

氙兘 8 \%

늘

인

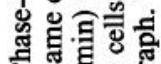

स

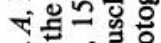

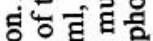

त्ञ

댕요

잉요

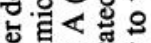

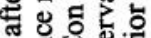

掟砳

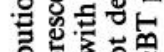

을 政㩆 论远

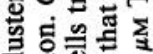
용 $N$ 记 0.

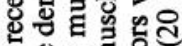
운

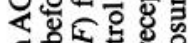
청 ष정워 ธี 뻔  영 迎岤 质它 ○. \%

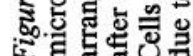


of clusters to form an annular shape. We demonstrated earlier that newly inserted receptors were mobile even though old receptors were immobilized by the Con A. We prefer the latter interpretation for the reason described in the Discussion.

\section{Discussion}

We examined the effect of Con A on the mobility of ACh receptors in the membrane and on nerve-induced receptor accumulation of nerve-muscle contacts and found that the mobility of receptors in the membrane and nerve-induced receptor accumulation are closely correlated under various experimental conditions. Namely, $100 \mu \mathrm{g} / \mathrm{ml}$ of Con A immobilized ACh receptors and also inhibited nerve-induced receptor accumulation, whereas $100 \mu \mathrm{g} / \mathrm{ml}$ Suc-Con A neither immobilized receptors nor blocked receptor accumulation. Even after old receptors were immobilized with Con $\mathrm{A}$, new receptors inserted after the treatment were mobile and the nerve did cause receptor accumulation. The concentration dependence of these 2 parameters, the mobility of receptors and the percentage of cells with nerve-induced receptor accumulation among nerve-contacted muscle cells, was similar. These observations are consistent with the idea that diffusely distributed mobile receptors migrate in the membrane to nerve-contact sites and form high receptor density regions in the postjunctional membrane. It is, however, difficult to rigorously exclude other possibilities, and we discuss alternative explanations of the effect of Con A.

Con A has various effects on cell-surface molecules. In HeLa cells, $50 \mu \mathrm{g} / \mathrm{ml}$ Con A cross-links receptors and forms micropatches, which are then pulled together to form a "cap" (Bourguignon and Singer, 1977). This phenomenon does not occur in Xenopus muscle cells in culture. The distribution of Con A receptors remains unchanged after treatment (Orida and Poo, 1978). We also observed that the distribution of $\mathrm{ACh}$ receptor clusters in Xenopus muscle cells was similar after Con A treatment. A similar observation has also been reported in cultured chick myotubes (Prives et al., 1979).

Relatively low concentrations of Con $\mathrm{A}(10 \mu \mathrm{g} / \mathrm{ml})$ reduce the turnover rate of ACh receptors in chick myotubes (Prives et al., 1979). We did not quantitatively examine the effect of Con A on the turnover rate of ACh receptors in Xenopus muscle cells. However, the rate of incorporation of new receptors after treatment with unlabeled $\alpha \mathrm{BT}$ and Con A was similar to that expected from the turnover rate in untreated cultures at $52 \mathrm{hr}$ (Brehm et al., 1983), judging from the fluorescence intensity measurement in microphotographs (Kidokoro and Brass, 1985). The fluorescence intensity of old ACh receptors declines during days in culture, as in untreated cultures, even after Con A treatment. Therefore, the effect of Con A on the turnover of ACh receptors in Xenopus muscle cells does not seem to be as great as reported in chick myotubes. Recently, Con A $(100 \mu \mathrm{g} / \mathrm{ml})$ was found to accelerate slightly the degradation rate of $\alpha \mathrm{BT}$ binding sites in Xenopus tail muscles: half-degradation time, $97 \pm 19 \mathrm{hr}(n=6)$ in controls; $79 \pm 9 \mathrm{hr}(n=9)$ in Con Atreated tails. (The tadpoles used were at stage 37-38, and the experiments were carried out at $20^{\circ} \mathrm{C}$; P. Brehm, personal communication.)

A more subtle effect of Con A was found in 3T3 cells. Locally applied Con A modulated diffusion of receptors on other parts of the cell membrane (global effect; Schlessinger et al., 1977a, b). In Xenopus muscle cells, however, newly inserted receptors moved even after old receptors were immobilized by Con A.

It appears that Con A has various secondary effects after crosslinking surface receptors. Even if the primary cross-linking effect occurs in all cases, the secondary effect may vary greatly from one cell type to another or may depend on the state of cells. It is most likely that Con A binds and immobilizes ACh receptors in Xenopus muscle cells. In this case, nerve is no longer able to cause receptor accumulation. These observations, however, do
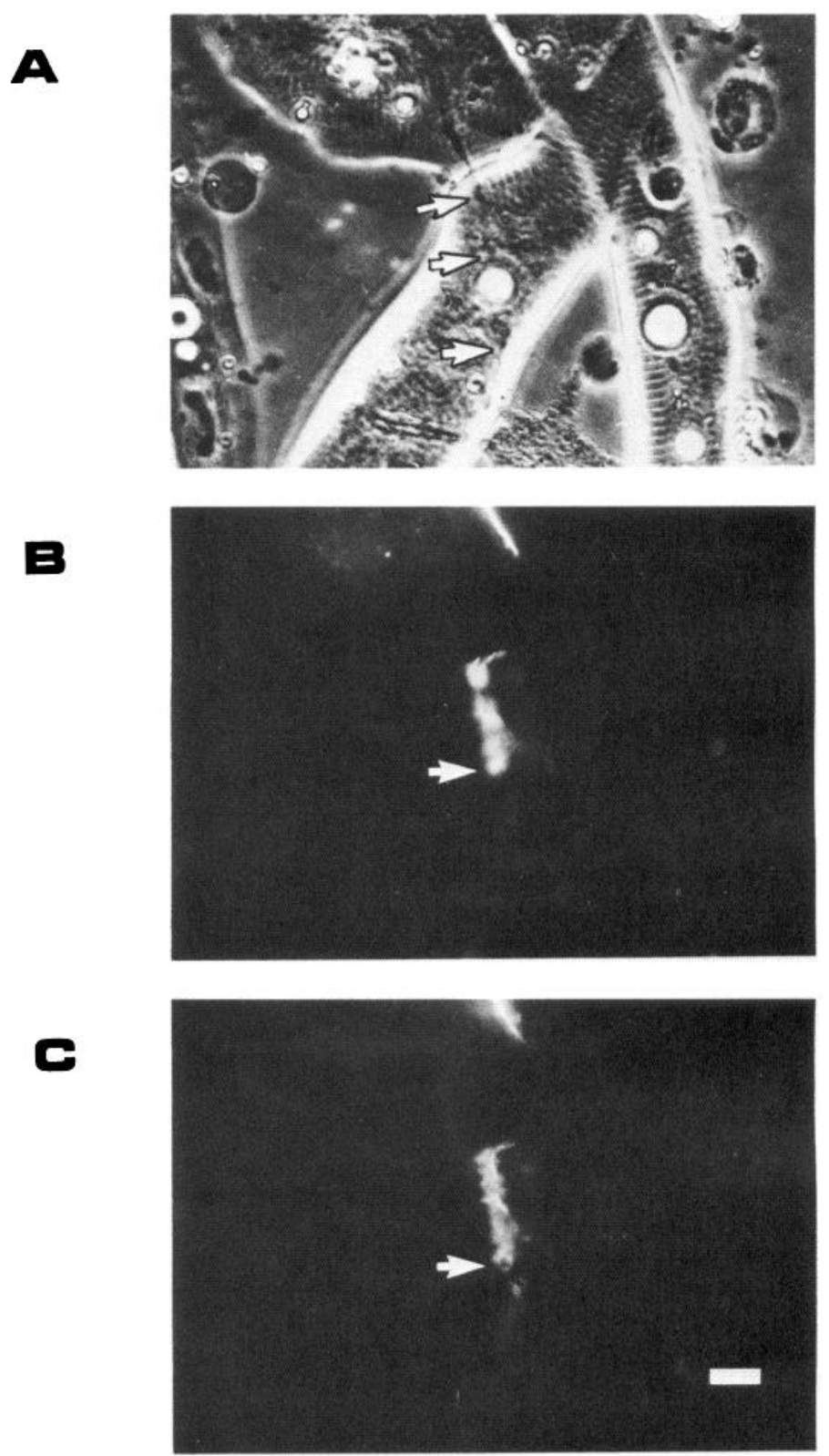

Figure 7. Annular shape of nerve-induced clusters. The nerve-muscle culture was treated with $2 \mu \mathrm{M}$ TMR- $\alpha \mathrm{BT}$ for $60 \mathrm{~min}$ and $100 \mu \mathrm{g} / \mathrm{ml}$ Con A for $15 \mathrm{~min}$. After washing thoroughly, the culture was incubated for $2 \mathrm{~d}$ at room temperature. The first picture was taken with $40 \mathrm{sec}$ exposure time. During this prolonged exposure, a majority of old ACh receptors were bleached out. Then, new ACh receptors were visualized by staining again with $2 \mu \mathrm{M}$ TMR- $\alpha \mathrm{BT}$. $A$, Phase-contrast micrograph. Arrow in $C$ indicates an annular structure after restaining. There is no such structure in $B$ at the corresponding spot (arrow), which was taken during the first exposure. Thus, $B$ depicts the distribution of Con A-immobilized old receptors. Bar in $C, 10 \mu \mathrm{m}$.

not indicate whether immobilization per se or its secondary effect is responsible for inhibition of nerve-induced receptor accumulation.

It has been demonstrated that at least some of the receptors in nerve-associated clusters are old ones that existed prior to nerve contact (Anderson and Cohen, 1977; Anderson et al., 1977). We will consider 3 possible mechanisms for relocation of old receptors.

1. Active and selective attraction of small receptor clusters to 
nerve contact, analogous to the mechanism involved in "capping" in B lymphocytes (Bourguignon and Singer, 1977). Surface receptors are cross-linked to form micropatches which are then pulled to one pole of the cell. We have previously observed the process of nerve-induced receptor accumulation in a sequential manner using an image intensifier and concluded that receptor clusters at the junction did not form by aggregation of small clusters being pulled together. Of course, it is possible that micropatches in Xenopus muscle cells might be too small to be seen in the optical fluorescence microscope. If receptors formed invisible micropatches when nerve contacted muscle and those micropatches were pulled together at nerve contact, we would expect the mobile fraction of receptors to decrease as the nerve contacts the muscle cells because micropatches have been shown to be associated with underlying actin filaments and most likely to be anchored (Bourguignon and Singer, 1977). However, the mobile fraction of ACh receptors was the same between muscle cells with and without nerve contact (Kuromi et al., 1985). Therefore, we conclude that this is an unlikely mechanism for nerve-induced receptor accumulation.

2. Active transportation of receptors through the cytoplasm. Receptors or the receptor-rich membrane could be internalized into small vesicles that are transported to the nerve-contact region and inserted into the surface membrane. In ultrastructural studies of newly formed neuromuscular junctions in culture, Nakajima et al. (1980) noted that "coated caveolae" were often associated at the postsynaptic membrane. Also at beadinduced receptor clusters, coated vesicles $60-100 \mathrm{~nm}$ in diameter were reported in the vicinity of bead-muscle contact (Peng and Cheng, 1982). These observations may support this mechanism for ACh receptor accumulation. If Con A prevents internalization of receptors, this mechanism would be blocked. Many observations described in this study can be explained by this mechanism. We showed, however, that new receptors were mobile and accumulated at the nerve-contact region even when old ones were immobilized by Con A. Since old and new receptors are mixed homogeneously at the diffusely distributed region, it may be difficult to sort out new receptors from old ones and to transport new ones selectively to the subsynaptic membrane. In order to accommodate all observations, this mechanism would become very elaborate. Therefore, we would consider this possibility seriously only if other alternatives are exhausted.

3. "Diffusion trap" mechanism in which freely diffusing $\mathrm{ACh}$ receptors in the membrane are trapped at the nerve-contact sites and form high-density regions. In this study we showed that Con A immobilized ACh receptors and prevented nerve-induced receptor accumulation under various experimental conditions. We prefer this mechanism over the one described above because of its simplicity and its ability to account for all observations without further elaboration.

We have so far dealt with the mechanism of redistribution of existing receptors. In addition to this mechanism, preferential insertion of newly formed receptors at the junctional region may occur. This mechanism is particularly attractive when we view the neuromuscular junction of adult animals, where a relatively small subsynaptic region contains an extremely high concentration of receptors. If receptors are inserted far from the junctional site it will take a long time to passively diffuse in the membrane to the junction. For a preferential insertion mechanism to work effectively, receptors have to be anchored or immobilized at the site of insertion. If inserted receptors were free to diffuse in the membrane, it is energetically difficult to maintain the concentration gradient at the edge of the subjunctional area by simply pumping in receptors at a spot (refer to the discussion in Almers et al., 1983). Therefore, we consider that the preferential insertion mechanism is closely linked to the receptor-immobilization device. Previously, we stained old and new receptors separately during the period of receptor accumulation and quantitatively determined their distribution; we found that the proportion of old and new receptors at all nerve-induced receptor clusters was similar to that at diffusely distributed extrajunctional regions. Therefore, we concluded that preferential insertion does not make a significant contribution in Xenopus cultures (Kidokoro and Brass, 1985). Recently, however, Role et al. (1985) have shown that in chick nerve-muscle cultures, the relative proportion of newly inserted receptors at the nerve-induced clusters is higher than at the preexisting "hot spots," and they concluded that preferential insertion of new receptors at the junctional region is the major mechanism for nerve-induced receptor accumulation. It should be noted that in their study the relative proportion of new receptors at the junction was not compared with that in the surrounding background region. Therefore, it is possible that receptors were inserted near the junctional area and accumulated at the junction by diffusion. Large, multinucleated chick myotubes may have this kind of mechanism to avoid the above-mentioned problem of a too-long diffusion pathway. On the other hand, Xenopus myotomal muscle cells are mononucleated and small (about $100 \mu \mathrm{m}$ in length and 10 $\mu \mathrm{m}$ in diameter at the stage of innervation). Therefore, the diffusion time is not great wherever in the membrane new receptors are inserted.

When old receptors were immobilized with Con A and new receptors separately stained, we found that new receptors accumulated around old ones in some areas along the nerve-contact regions. This observation suggests that new receptors are diffusible in the membrane and are trapped at the peripheral fringe of growing clusters. Indeed, with the fluorescence photobleaching recovery technique we showed that receptors inserted after the Con A treatment are mobile. A similar pattern of accumulation of new receptors has been reported at ectopic synapses in the adult rat skeletal muscle (Weinberg et al., 1981).

All of our observations were compatible with the diffusion trap mechanism, which is the simplest of the available alternatives. However, further quantitative studies are required for determining which molecular mechanism uniquely underlies nerve-induced receptor accumulation.

\section{References}

Almers, W., P. R. Stanfield, and W. Stuhmer (1983) Lateral distribution of sodium and potassium channels in frog skeletal muscle: Measurements with a patch-clamp technique. J. Physiol. (Lond.) 336: 261-284.

Anderson, M. J., and M. W. Cohen (1977) Nerve-induced and spontaneous redistribution of acetylcholine receptors on cultured muscle cells. J. Physiol. (Lond.) 268: 757-773.

Anderson, M. J., M. W. Cohen, and E. Zorychta (1977) Effects of innervation on the distribution of acetylcholine receptors on cultured muscle cells. J. Physiol. (Lond.) 268: 731-756.

Axelrod, D., D. E. Koppel, J. Schlessinger, E. Elson, and W. W. Webb (1976a) Mobility measurement by analysis of fluorescence photobleaching recovery kinetics. Biophys. J. 16: 1055-1069.

Axelrod, D., P. Ravdin, D. E. Koppel, J. Schlessinger, W. W. Webb, E. L. Elson, and T. R. Podleski (1976b) Lateral motion of fluorescently labeled acetylcholine receptors in membranes of developing muscle fibers. Proc. Natl. Acad. Sci. USA 73: 4594-4598.

Bevan, S., and J. H. Steinbach (1977) The distribution of $\alpha$-bungarotoxin sites on mammalian skeletal muscle developing in vitro. J. Physiol. (Lond.) 267: 195-213.

Bourguignon, L. Y. W., and S. L. Singer (1977) Transmembrane interactions and the mechanism of capping of surface receptors by their specific ligands. Proc. Natl. Acad. Sci. USA 74: 5031-5035.

Braithwaite, A. E., and A. J. Harris (1979) Neural influence on acetylcholine receptor clusters in embryonic development of skeletal muscles. Nature 279: 549-551.

Brehm, P., E. Yeh, J. Patrick, and Y. Kidokoro (1983) Metabolism of acetylcholine receptors on embryonic amphibian muscle. J. Neurosci. 3: 101-107.

Brockes, J. P., and Z. W. Hall (1975) Acetylcholine receptors in normal 
and denervated rat diaphragm muscle. II. Comparison of junctional and cxtrajunctional receptors. Biochcmistry 14: 2100-2106.

Bursztajn, S., S. A. Berman, J. McManaman, and S. H. Appel (1983) Acetylcholine receptors are preferentially inserted and removed at clusters in cultured rat myotubes. Soc. Neurosci. Abstr. 9: 1059.

Edwards, C., and H. L. Frisch (1976) A model for the localization of acetylcholine receptors at the muscle endplate. J. Neurobiol. 7: 377381.

Gunther, G. R., J. L. Wang, I. Yahara, B. A. Cunningham, and G. M. Edelman (1973) Concanavalin A derivatives with altered biological activities. Proc. Natl. Acad. Sci. USA 70: 1012-1016.

Kidokoro, Y. (1984) Two types of miniature endplate potentials in Xenopus nerve-muscle cultures. Neurosci. Res. 1: 157-170.

Kidokoro, Y., and B. Brass (1985) Redistribution of acetylcholine receptors during neuromuscular junction formation in Xenopus cul tures. J. Physiol. (Paris) 80: 212-220.

Kidokoro, Y., M. J. Anderson, and R. Gruener (1980) Changes in synaptic potential properties during acetylcholine receptor accumulation and neurospecific interaction in Xenopus nerve-muscle cell culture. Dev. Biol. 78: 464-483.

Kuromi, H., and Y. Kidokoro (1983) Formation and dispersal of acetylcholine receptor clusters at nerve-muscle junction in Xenopus culture. Soc. Neurosci. Abstr. 9: 1179.

Kuromi, H., and Y. Kidokoro (1984a) Nerve disperses pre-existing acetylcholine receptor clusters prior to induction of receptor accumulation in Xenopus muscle cultures. Dev. Biol. 103: 53-61.

Kuromi, H., and Y. Kidokoro (1984b) Denervation disperses acetylcholine receptor clusters at the neuromuscular junction in Xenopus cultures. Dev. Biol. 104: 421-427.

Kuromi, H., B. Brass, and Y. Kidokoro (1985) Formation of acetylcholine receptor clusters at neuromuscular junction in Xenopus cultures. Dev. Biol. 109: 165-176.

Meunier, J.-C., R. Sealock, R. Olsen, and J.-P. Changeux (1974) Purification and properties of the cholinergic receptor protein from Electrophorus electrus electric tissue. Eur. J. Biochem. 45: 371-394.

Nakajima, Y., Y. Kidokoro, and F. G. Klier (1980) The development of functional neuromuscular junctions in vitro: An ultrastructural and physiological study. Dev. Biol. 77: 52-72.
Nicolson, G. L. (1974) The interactions in lectins with animal cell surface. Int. Rev. Cytol. 39: 89-190.

Orida, N., and M.-M. Poo (1978) Electrophoretic movement and localization of acetylcholine receptors in the embryonic muscle cell membrane. Nature $275: 31-35$.

Peng, H. B., and P.-C. Cheng (1982) Formation of postsynaptic specializations induced by latex beads in cultured muscle cells. J. Neurosci. 2: 1760-1774.

Poo, M.-M. (1982) Rapid lateral diffusion of functional ACh receptors in embryonic muscle cell membrane. Nature 295: 332-334.

Prives, J., L. Hoffman, R. Tarrab-Hazdai, S. Fuchs, and A. Amsterdam (1979) Ligand induced changes in stability and distribution of acetylcholine receptors on surface membrane of muscle cells. Life Sci. 24: 1713-1718.

Role, L. W., V. R. Matossian, R. J. O'Brien, and G. D. Fischbach (1985) On the mechanism of acetylcholine receptor accumulation at newly formed synapses on chick myotubes. J. Neurosci. 5: 2197-2204.

Schlessinger, J., D. Axelrod, D. E. Koppel, W. W. Webb, and E. L. Elson (1977a) Lateral transport of a lipid probe and labeled protein on a cell membrane. Science 195: 307-309.

Schlessinger, J., E. L. Elson, W. W. Webb, I. Yahara, U. Rutishauser, and G. M. Edelman (1977b) Receptor diffusion on cell surfaces modulated by locally bound concanavalin A. Proc. Natl. Acad. Sci. USA 74: $1110-1114$.

Schreiner, G. F., and E. R. Unanue (1976) Membrane and cytoplasmic changes in B lymphocytes induced by ligand-surface immunoglobulin interaction. In Advances in Immunology, F. J. Dixon and H. G. Kunkel, eds., pp. 37-165, Academic, New York.

Stya, M., and D. Axelrod (1983) Diffusely distributed acetylcholine receptors can participatc in cluster formation on cultured rat myotubes. Proc. Natl. Acad. Sci. USA 80: 449-453.

Weinberg, C. B., C. G. Reiness, and Z. W. Hall (1981) Topographical segregation of old and new acetylcholine receptors at developing ectopic endplates in adult rat muscle. J. Cell Biol. 88: 215-218.

Ziskind-Conhaim, L., and J. J. Bennett (1982) The effect of electrical inactivity and denervation on the distribution of acetylcholine receptors in developing rat muscle. Dev. Biol. 90: 185-197. 